\title{
Pengaruh Stabilitas Penjualan dan Struktur Aktiva Terhadap Struktur Modal
}

\author{
(Studi Empiris pada Perusahaan Sub Sektor Perdagangan Besar \\ (Barang Produksi dan Barang Konsumsi) yang terdaftar di Bursa Efek \\ Indonesia Periode Tahun 2013-2017)
}

\author{
JAENAL ABIDIN \\ Universitas Pamulang \\ Jaenalabidin328@gmail.com
}

\author{
ILHAM HIDAYAT \\ Universitas Pamulang \\ Hidayatilham7275@gmail.com
}

\begin{abstract}
The purpose of this study was to determine the effect of sales stability on the capital structure and to determine the effect of asset structure on capital structure, and to determine the effect of sales stability and asset structure together on capital structure in large trading sub-sector companies (production goods and consumer goods ) period 2013-2017.The type of research used is quantitative associative, with the method of collecting data using secondary data obtained from the Indonesia Stock Exchange. The population in this study are large-scale trade sub-sector companies (production goods and consumer goods) listed on the Indonesia Stock Exchange. Sampling using the purposive sampling method, there are 45 samples. The method of analysis uses multiple linear regression. The results of the study can be concluded that sales stability has a significant effect on capital structure, asset structure has a significant influence on capital structure, and sales stability and asset structure together (simultaneously) affect the capital structure.
\end{abstract}

Keywords: Stability of Sales, Asset Structure, and Capital Structure

\section{PENDAHULUAN}

\subsection{Latar Belakang}

Dunia bisnis yang sedang memasuki era globalisasi mengakibatkan persaingan semakin tajam, sehingga setiap perusahaan dituntut untuk senantiasa berproduksi secara efisien bila ingin tetap memiliki keunggulan daya saing. Perusahaan sebagai suatu entitas yang beroperasi dengan menerapkan prinsipprinsip ekonomi, umumnya tidak hanya berorientasi pada pencapaian laba maksimal, tetapi juga berusaha meningkatkan nilai perusahaan dan kemakmuran pemiliknya, untuk itu perusahaan memiliki rencana strategis dan taktis yang disusun dalam rangka pencapaian tujuan yang telah ditetapkan. Salah satu aspek penting untuk mengimplementasikan rencana tersebut adalah struktur modal.

Modal merupakan unsur yang sangat penting bagi perusahaan dalam membiayai kegiatan operasional dan juga keberlangsungan dan perkembangan perusahaan. Perusahaan dapat menggunakan modal sendiri (equity) dan hutang (debt) yang terbagi hutang jangka pendek yaitu hutang yang harus dilunasi kurang dari satu tahun dan hutang jangka panjang yaitu hutang yang harus dilunasi lebih dari satu tahun. Menurut Harjitno dan Martono (2014:256) struktur modal merupakan 
perbandingan pendanaan jangka panjang perusahaan yang ditunjukan dengan perbandingan hutang jangka panjang dengan modal sendiri. Dengan mempertimbangkan faktor-faktor tersebut diharapkan dana yang diperoleh baik dana internal dan eksternal keputusan yang tepat dan dapat dipergunakan sebaik mungkin sehingga tujuan perusahaan tercapai.

Industri perdagangan merupakan industri yang mendominasi perusahaanperusahaan yang terdaftar di Bursa Efek Indonesia (BEI). Banyaknya perusahaan industri dan kondisi perekonomian saat ini telah menciptakan persaingan antar perusahaan. Persaingan membuat setiap perusahaan berusaha meningkatkan kinerja untuk mencapai tujuan seperti laba yang tinggi. Upaya mengantisipasi kondisi tersebut, maka manajer keuangan perusahaan harus hati-hati dalam menentukan struktur modal perusahaan. Dengan adanya perencanaan yang matang dalam menentukan struktur modal, diharapkan perusahaan dapat meningkatkan nilai perusahaan dan lebih unggul dalam persaingan bisnis agar tujuan perusahaan dapat tercapai. Besar kecilnya suatu perusahaan akan berpengaruh terhadap struktur modal, semakin besar perusahaan maka akan semakin besar pada kesempatan melakukan investasi dan memperoleh akses ke sumber modal.

Adapun faktor-faktor yang mempengaruhi struktur modal perusahaan dapat menjadi hal yang penting dalam mempertimbangkan dan menentukan komposisi modal yang akan digunakan yaitu stabilitas penjualan dan struktur aktiva. Stabilitas penjualan sangat berpengaruh terhadap struktur modal menurut Copeland and Weston (2008:20), stabilitas penjualan dan rasio hutang berkaitan erat sekali. Bila stabilitas penjualan dan laba lebih besar, maka beban hutang tetap yang terjadi pada suatu perusahaan akan mempunyai risiko yang lebih kecil dibandingkan dengan perusahaan yang penjualan dan labanya menurun tajam. yang relatif tidak sebanding. Menurut penelitian Mawikere dan Rate (2015:149-158) menunjukan stabilitas penjualan berpengaruh signifikan terhadap struktur modal. Namun penelitian ini menolak penelitian dari Vitriasari \& Indarti (2012), yang menyatakan bahwa tidak ada pengaruh antara stabilitas penjualan dengan struktur modal.

Struktur aktiva merupakan variabel yang penting dalam keputusan pendanaan perusahaan karena aktiva tetap berhubungan dengan proses produksi perusahaan untuk mendapatkan ataupun meningkatkan laba perusahaan. Semakin tinggi aktiva tetap yang dimiliki perusahaan akan mengoptimalkan proses produksi perusahaan yang pada akhirnya dapat menghasilkan laba yang maksimal. Penelitian yang dilakukan oleh Putri (2012), yang membuktikan bahwa variabel struktur aktiva berpengaruh positif dan signifikan terhadap struktur modal. Dengan demikian apabila penjualan stabil maka semakin tinggi struktur modalnya. Jika struktur modal semakin tinggi ini berarti struktur aktiva juga semakin tinggi dan keadaan tersebut berarti semakin tinggi pula aktiva tetap yang dapat dijadikan agunan hutang oleh perusahaan tersebut, dan sebaliknya struktur aktiva yang semakin rendah, maka semakin rendah pula kemampuan perusahaan dalam memenuhi hutang jangka panjang perusahaan.

\subsection{Perumusan Masalah}

Berdasarkan latar belakang masalah di atas, dapat disusun permasalahan sebagai berikut:

1. Apakah stabilitas penjualan berpengaruh terhadap struktur modal

2. Apakah struktur aktiva berpengaruh terhadap struktur modal 
3. Apakah stabilitas penjualan dan strukur aktiva berpengaruh terhadap struktur modal

\subsection{Tujuan Penelitian}

Berdasarkan permasalahan yang telah diuraikan di atas, maka tujuan penelitian ini adalah:

1. Untuk mengetahui seberapa besar pengaruh stabilitas penjualan terhadap struktur modal

2. Untuk mengetahui seberapa besar pengaruh struktur aktiva terhadap struktur modal

3. Untuk mengetetahui seberapa besar pengaruh stabilitas penjualan dan struktur aktiva secara bersama-sama terhadap struktur modal

\section{TINJAUAN PUSTAKA}

\subsection{Signalling Theory}

Teori ini dikembangkan oleh Ross pada tahun 1979. Ross menyarankan perusahaan dengan leverage yang besar dapat dipakai manajer sebagai sinyal optimis akan masa depan perusahaan. Signalling theory ini muncul karena adanya permasalahan asimetris informasi (situasi dimana manajer lebih mengetahui informasi tentang operasi dan prospek perusahaan ke depannya dibandingkan investor luar). Menurut Rahman dalam Aulia (2017) Signalling theory merupakan langkahlangkah manajemen dalam perusahaan yang seharusnya memberikan petunjuk kepada investor tentang bagaimana manajemen memandang prospek perusahaan.

\subsection{Struktur Modal}

Keputusan untuk memilih sumber pembiayaan merupakan keputusan bidang keuangan yang sangat penting bagi perusahaan. Rasio hutang jangka panjang terhadap rasio modal sendiri (Long time debt to equity ratio) menggambarkan struktur modal perusahaan dan rasio hutang terhadap modal akan menentukan besarnya leverage keuangan yang digunakan perusahaan Weston dan Copeland dalam Aulia (2017). Riyanto (2010:293) menyatakan apabila suatu perusahaan dalam memenuhi kebutuhan dananya mengutamakan pemenuhan dengan sumber dari dalam perusahaan akan sangat mengurangi ketergantungannya kepada pihak luar.

Menurut Kasmir (2013:158) analisis struktur modal dapat dilakukan dengan menggunakan cara ukuran sebagai berikut:

\subsubsection{Debt to Equity Ratio (DER)}

Adapun menurut Kasmir (2013:158) rumus DER sebagai berikut:

$$
\text { DER }=\frac{\text { Total Hutang }}{\text { Ekuitas }} \times 100 \%
$$

\subsection{Stabilitas Penjualan}

Menurut Copeland and Weston (2008:20), bila stabilitas penjualan dan laba bersih besar, maka beban hutang tetap yang terjadi pada suatu perusahaan akan mempunyai resiko yang lebih kecil dibandingkan dengan perusahaan penjualan dan labanya menurun tajam, bila laba kecil, maka perusahaan akan menemui kesulitan untuk membayar bunga tetap dari obligasi. Perusahaan yang penjualannya relatif stabil dapat lebih aman menggunakan lebih banyak hutang dan menanggung beban tetap lebih tinggi dari pada perusahaan dengan penjualan tidak stabil. Stabilitas penjualan dan rasio hutang berkaitan erat sekali Brigham \& Houston dalam Mawikere dan Rate (2015:149-158).

\subsubsection{Rasio Stabilitas Penjualan}

Menurut Munawir (2010:89), rasio ini ialah untuk mengukur tingkat keuntungan yang dapat dicapai oleh perusahaan dihubungkan dengan penjualannya.tetap dari obligasi. Berikut rumus untuk mengukur variabel stabilitas penjualan: 


$$
\mathrm{NPM}=\frac{\text { Penjualan }}{\text { Laba Bersih }} \times 100 \%
$$

Sumber : Mawikere dan Rate (2015:149-158)

\subsection{Struktur Aktiva}

Bambang Riyanto (2010:22), menyatakan bahwa struktur aktiva atau struktur kekayaan adalah perimbangan atau perbandingan baik dalam artian absolut maupun dalam artian relatif antara aktiva lancar dengan aktiva tetap. Menurut Bambang Riyanto (2008:19), struktur aktiva terdiri dari aktiva lancar dan aktiva tetap, Aktiva lancar adalah aktiva yang habis dalam satu kali berputar dalam proses produksi, dan proses perputarannya dalam jangka waktu yang pendek (umumnya kurang dari satu tahun). Sedangkan aktiva tetap adalah aktiva yang tahan lama yang secara berangsur-angsur habis turut serta dalam proses produksi. Dari penjelasan di atas dapat disimpulkan bahwa aktiva atau aset adalah segala sumber daya dan harta yang dimiliki perusahaan untuk digunakan dalam operasinya.

\subsubsection{Rasio Struktur Aktiva}

Mawikere dan Rate (2015:149158), struktur aktiva menggambarkan besarnya aktiva yang dapat dijaminkan perusahaan ketika perusahaan melakukan pinjaman kepada pihak kreditur. Struktur aktiva merupakan proporsi aktiva tetap yang dimiliki perusahaan.

Adapun formulasi untuk pengukuran variabel dari struktur aktiva adalah sebagai berikut:

$$
\text { Struktur Aktiva }=\frac{\text { Aktiva Tetap }}{\text { Total Aktiva }} \times 100 \%
$$

Sumber: Maryanti (2016)

\subsection{Penelitian Terdahulu}

Penelitian yang pernah dilakukan oleh Mawikere dan Rate (2015), dengan judul Pengaruh stabilitas Penjualan dan struktur aktiva terhadap struktur modal pada perusahaan automotive and allied product yang terdaftar di BEI tahun 2010-2013 menemukan, bahwa stabilitas penjualan dan struktur aktiva secara sama-sama berpengaruh terhadap struktur modal pada perusahaan automotive and allied product yang terdaftar di BEI.

\subsection{Kerangka Konseptual}

Kerangka konseptual dapat digambarkan sebagai berikut :

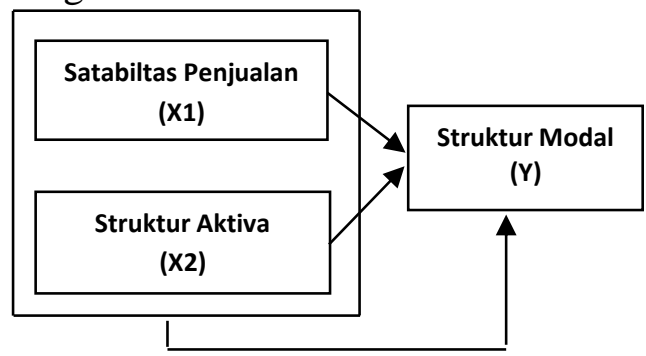

Dari gambar kerangkal konseptual tersebut maka hipotesis penelitian adalah :

Stabilitas Penjualan dan Struktur Aktiva berpengaruh secara parsial terhadap Struktur Modal (Studi Empiris pada Perusahaan Sub Sektor Perdagangan Besar (Barang Produksi dan Barang Konsumsi) yang terdaftar di Bursa Efek Indonesia Periode Tahun 20132017). Stabilitas Penjualan dan Struktur Aktiva berpengaruh secara simultan terhadap Struktur Modal (Studi Empiris pada Perusahaan Sub Sektor Perdagangan Besar (Barang Produksi dan Barang Konsumsi) yang terdaftar di Bursa Efek Indonesia Periode Tahun 2013-2017).

\section{METODE PENELITIAN}

\subsection{Jenis Penelitian}

Jenis dan sumber data jenis yang digunakan dalam penelitian ini adalah data sekunder, sumber data yang diperoleh melalui dokumen-dokumen perusahaan dan laporanlaporan perusahaan lainnya. Data diperoleh dari laporan keuangan perusahaan sub sektor 
perdagangan besar (barang produksi \& barang konsumsi) yang terdaftar di Bursa Efek Indonesia (BEI) periode 2013-2017.

Populasi dalam penelitian ini adalah 37 perusahaan sub sektor perdagangan besar (barang produksi dan barang konsumsi) yang terdaftar di Bursa Efek Indonesia (BEI) periode 2013-2017. Sampel dalam penelitian ini adalah perusahaan-perusahaan yang dipilih dengan teknik purposive sampling. Identifikasi dan defenisi operasional variabel penelitian variabel independen sama dengan variabel bebas yang artinya variabel yang menjadi pengaruh atau yang menjadi sebab perubahannya. Variabel dependen atau disebut juga variabel terikat yang artinya variabel yang dipengaruhi atau yang menjadi akibat.

\section{HASIL PENELITIAN DAN PEMBAHASAN}

Metode analisis pendekatan ini menggunakan pendekatan dengan metode kuantitatif. Jenis penelitian ini adalah menggunakan deskriptif. Dalam penelitian ini metode analisis data yang digunakan adalah metode analisis statistik dengan menggunakan software SPSS 24. Untuk pengujian hipotesis dilakukan anlisis regresi linear berganda model regresi yang digunakan adalah sebagai berikut :

linier sederhana dapat dicari dengan rumus :

$$
Y=\alpha+\beta x 1+\beta x 2+e
$$

\section{Dimana :}

$\mathrm{Y}=$ Struktur modal perusahaan

$\alpha=$ Nilai Konstanta

$\beta=$ Koefisien Regresi (Beta)

$\mathrm{X}_{1}=$ Stabilitas Penjualan

$\mathrm{X}_{2}=$ Struktur Aktiva

$\mathrm{E}=$ Standar Error

Pengujian asumsi klasik yang dilakukan terdiri atas uji normalitas, uji multikolinearitas, uji heterokedastisitas $\mathrm{xn}$ uji utokorelasi. Hasil pengujian asumsi klasik ini menggunkan software SPSS 24.

\subsection{Hasil Analisis}

\section{Uji Normalitas}

Ada dua cara untuk mendeteksi uji normalitas dengan analisis statistik dan analisi grafik.

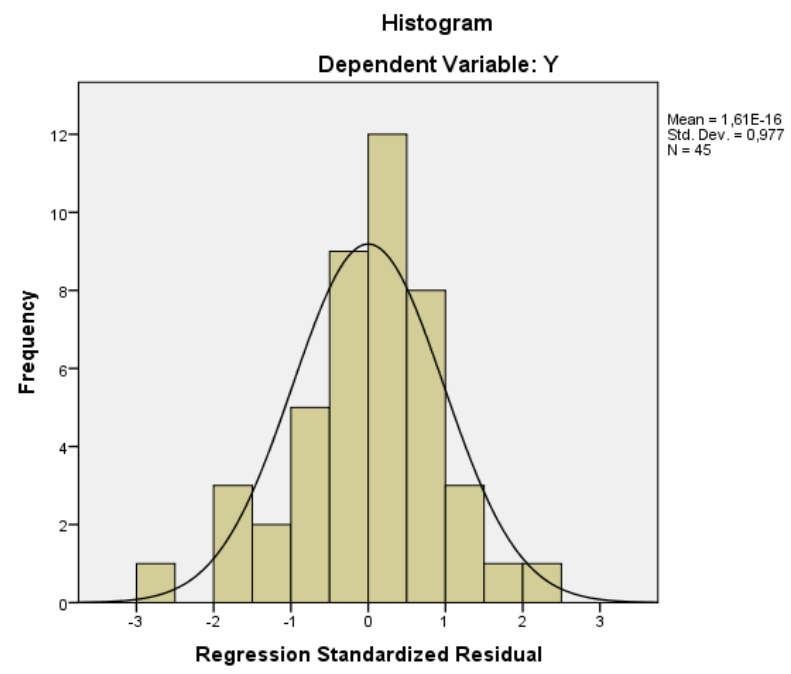

Sumber: Hasil olah data SPSS 24

Untuk melihat normalitas residual adalah dengan melihat grafik histogram, pada grafik diatas garis mendekati diagonal maka garfik tersebut dikatakan normal. Grafik histogram adalah grafik yang membandingkan antara data observasi dengan distribusi yang mendekati distribusi normal.

\section{Multikolineritas}

\begin{tabular}{|c|c|c|c|c|c|c|c|}
\hline \multicolumn{8}{|c|}{ Coefficients $^{a}$} \\
\hline \multirow[b]{2}{*}{ Model } & \multicolumn{2}{|c|}{$\begin{array}{c}\text { Unstanda } \\
\text { rdized } \\
\text { Coefficie } \\
\text { nts }\end{array}$} & \multirow{2}{*}{$\begin{array}{c}\text { Standar } \\
\text { dized } \\
\text { Coeffic } \\
\text { ients } \\
\\
\text { Beta }\end{array}$} & \multirow[b]{2}{*}{$\mathrm{t}$} & \multirow[b]{2}{*}{$\begin{array}{l}\mathrm{Si} \\
\mathrm{g} .\end{array}$} & \multicolumn{2}{|c|}{$\begin{array}{c}\text { Collinearit } \\
\text { y } \\
\text { Statistics }\end{array}$} \\
\hline & B & $\begin{array}{c}\text { Std. } \\
\text { Erro } \\
\mathrm{r} \\
\end{array}$ & & & & $\begin{array}{l}\text { Toler } \\
\text { ance }\end{array}$ & $\begin{array}{l}\text { VI } \\
\text { F }\end{array}$ \\
\hline $\begin{array}{l}\text { (Cons } \\
\operatorname{tant})\end{array}$ & $\begin{array}{r}, 73 \\
3\end{array}$ & ,197 & & $\begin{array}{r}3,7 \\
22\end{array}$ & $\begin{array}{l}, 0 \\
0 \\
1\end{array}$ & & \\
\hline
\end{tabular}




\begin{tabular}{|l|r|r|r|r|r|r|r|}
\hline SP &, 01 &, 002 &, 777 & 9,1 &, 0 &, 700 & 1,4 \\
& 8 & & & 62 & 0 & & 28 \\
& & & & & 0 & & \\
\hline SA & - &, 645 &,- 179 & - &, 0 &, 700 & 1,4 \\
& 1,3 & & & 2,1 & 4 & & 28 \\
& 58 & & & 06 & 1 & & \\
\hline
\end{tabular}

Sumber: Hasil olah data SPSS 24.

Berdasarkan tabel diatas data hasil pengujian diatas, dapat dilihat bahwa angka pada kolom nilai tolerance sebesar 0,700 dimana mendekati angka 1, dan nilai VIF sebesar 1,428 dimana < 10. Hal ini dapat disimpulkan bahwa tidak terdapat multikolineritas pada penelitian ini.

\section{Heteroskedastisitas}

\begin{tabular}{|c|c|c|c|c|c|}
\hline \multicolumn{6}{|c|}{ Coefficients $^{\mathbf{a}}$} \\
\hline \multirow[b]{2}{*}{ Model } & $\begin{array}{l}\text { Unst } \\
\text { Coe }\end{array}$ & $\begin{array}{l}\text { indardiz } \\
\text { ed } \\
\text { ficients }\end{array}$ & $\begin{array}{c}\text { Standardiz } \\
\text { ed } \\
\text { Coefficien } \\
\text { ts } \\
\end{array}$ & & \\
\hline & B & $\begin{array}{l}\text { Std. } \\
\text { Error }\end{array}$ & Beta & $\mathrm{t}$ & Sig \\
\hline \begin{tabular}{l|l}
1 & $($ Constan \\
t)
\end{tabular} & $\begin{array}{r}51 \\
2 \\
\end{array}$ & ,116 & & $\begin{array}{r}4,39 \\
9\end{array}$ & $\begin{array}{r}, 00 \\
0\end{array}$ \\
\hline $\begin{array}{l}\text { stabilitas } \\
\text { penjuala } \\
\mathrm{n}\end{array}$ & $\begin{array}{r}, 00 \\
0\end{array}$ & ,001 & ,064 & ,390 & $\begin{array}{r}, 69 \\
9\end{array}$ \\
\hline $\begin{array}{l}\text { struktur } \\
\text { aktiva }\end{array}$ & $\begin{array}{r}- \\
93 \\
9 \\
\end{array}$ & ,381 &,- 407 & $\begin{array}{r}2,46 \\
4\end{array}$ & $\begin{array}{r}, 01 \\
8\end{array}$ \\
\hline
\end{tabular}

Sumber: Hasil olah data SPSS 24

Berdasarkan tabel diatas hasil pengolahan data SPSS 24, diketahui bahwa nilai signifikansi variabel Stabilitas Penjualan (X1) sebesar 0,699 lebih besar dari 0,05 , artinya tidak terjadi heteroskedastisitas pada variabel Stabilitas Penjualan (X1). Sementara itu, diketahui nilai signifikansi variabel Struktur Aktiva (X2) yakni 0,018 lebih besar dari 0,05, artinya tidak terjadi heteroskedastisitas pada variabel Struktur Aktiva (X2). Yang artinya data dapat dilanjutkan dalam pengujian regresi berikutnya.

\section{Autokorelasi}

\begin{tabular}{|l|c|c|c|c|c|}
\hline \multicolumn{7}{|c|}{ Model Summary } \\
\hline
\end{tabular}

Sumber: Hasil olah data SPSS 24

Berdasarkan tabel diatas, dapat diketahui bahwa nilai DW sebesar 0,842 . Nilai ini akan dibanding dengan nilai tabel signifikan 5\%, jumlah sampel $45(\mathrm{n}-45)$ dan jumlah variabel 3 (K-3), maka akan didapat nilai batas bawah (dl) sebesar 1,3832 dan nilai batas atas (du) sebesar 1,6662. Nilai DW lebih kecil dari Du yaitu sebesar 0,842 $<1,6662$ dan nilai dari (4-DW) lebih besar 3,158 dari Du yaitu $(4-0,842)>1,6662=$ $3,158>1,6662$ maka dapat disimpulkan bahwa dalam penelitian ini tidak terdapat autokorelasi positif maupun negatif.

\section{Uji Koefisien Determinasi}

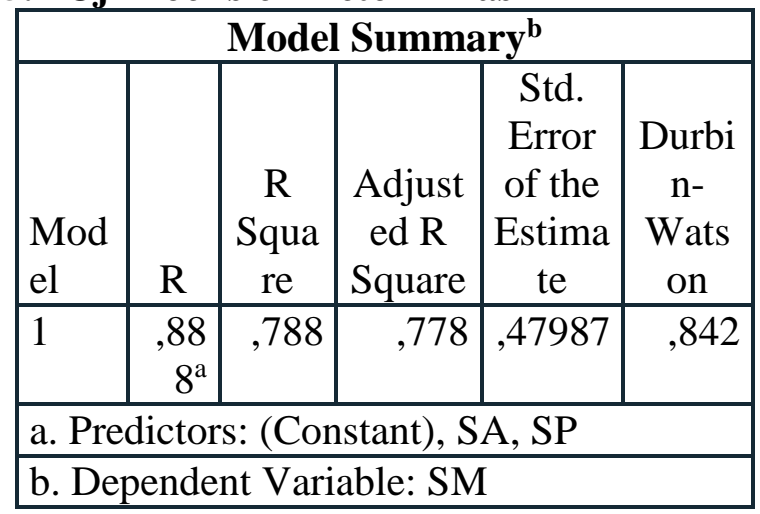

Sumber: Hasil olah data SPSS 24

Koefesien determinasi ditunjukan untuk mengetahui seberapa besar kemampuan model dalam menerangkan variabel independen terhadap variabel dependen. Dimana nilai $\left(\mathrm{R}^{2}\right)$ sebesar $78,8 \%$ Artinya terdapat $21,2 \%$ variabel lain yang dapat meningkatkan struktur modal. 


\section{Uji t (Parsial)}

\begin{tabular}{|c|c|c|c|c|c|c|c|}
\hline & & & efficien & & & & \\
\hline & $\begin{array}{l}\text { Un } \\
\text { dar } \\
\mathrm{Cos} \\
\mathrm{e}\end{array}$ & $\begin{array}{l}\text { dan } \\
\text { dize } \\
\text { ffici } \\
\text { its }\end{array}$ & $\begin{array}{l}\text { Stand } \\
\text { ardize } \\
\mathrm{d} \\
\text { Coeffi } \\
\text { cients }\end{array}$ & & & $\begin{array}{l}\text { Collir } \\
\text { rity } \\
\text { Statis }\end{array}$ & \\
\hline Model & B & $\begin{array}{l}\text { Std } \\
\cdot \\
\text { Err } \\
\text { or }\end{array}$ & Beta & $\mathrm{t}$ & $\begin{array}{l}\text { S } \\
\text { i } \\
\text { g. }\end{array}$ & $\begin{array}{c}\text { Tole } \\
\text { ranc } \\
\mathrm{e}\end{array}$ & $\begin{array}{c}\mathrm{V} \\
\mathrm{IF}\end{array}$ \\
\hline $\begin{array}{c}\text { (Con } \\
\text { stant } \\
)\end{array}$ & $\begin{array}{l}7 \\
33\end{array}$ & $\begin{array}{c}19 \\
7\end{array}$ & & $\begin{array}{c}3, \\
72 \\
2\end{array}$ & $\begin{array}{l}, 0 \\
0 \\
1\end{array}$ & & \\
\hline SP & $\begin{array}{l}0 \\
18\end{array}$ & $\begin{array}{c}, 00 \\
2\end{array}$ & ,777 & $\begin{array}{c}9, \\
16 \\
2\end{array}$ & $\begin{array}{l}, 0 \\
0 \\
0\end{array}$ & ,700 & $\begin{array}{c}1, \\
42 \\
8\end{array}$ \\
\hline $\mathrm{SA}$ & $\begin{array}{c}- \\
1, \\
35 \\
8\end{array}$ & $\begin{array}{c}, 64 \\
5\end{array}$ &,- 179 & $\begin{array}{c}- \\
2, \\
10 \\
6\end{array}$ & $\begin{array}{l}0 \\
4 \\
1\end{array}$ & ,700 & $\begin{array}{c}1, \\
42 \\
8\end{array}$ \\
\hline
\end{tabular}

Sumber: Hasil olah data SPSS 24

Berdasarkan tabel diatas, dapat diperoleh hasil variabel Stabilitas penjualan memiliki nilai signifikan sebesar 0,000. Nilai signifikan lebih kecil dari nilai standar signifikan 0,05 atau $0,000<0,05$, maka $\mathrm{H}_{1}$ diterima variabel. Variabel stabilitas penjualan memiliki thitung 9,162 dengan $t_{\text {tabel }}$ 2,01808 jadi thitung $>t_{\text {tabel }}$ dapat disimpulkan bahwa variabel stabilitas penjualan memiliki konstribusi terhadap struktur modal dan variabel struktur aktiva memiliki nilai signifikan sebesar 0,041. Nilai signifikan lebih kecil dari nilai standar signifikan sebesar 0,05 atau 0,041 <0,05 maka $\mathrm{H}_{2}$ diterima. Variabel struktur aktiva memiliki $t_{\text {hitung }} 2,106$ dengan $t_{\text {tabel }} 2,01808$ jadi $t_{\text {hitung }}>$ $t_{\text {tabel }}$ dapat disimpulkan bahwa variabel strtuktur aktiva memiliki kontribusi terhadap struktur modal.

\section{Uji F (Simultan)}

\begin{tabular}{|c|c|c|c|c|c|}
\hline \multicolumn{6}{|c|}{ ANOVA $^{a}$} \\
\hline Model & $\begin{array}{l}\text { Sum } \\
\text { of } \\
\text { Squar } \\
\text { es }\end{array}$ & $\begin{array}{l}\mathrm{d} \\
\mathrm{f}\end{array}$ & $\begin{array}{c}\text { Mea } \\
\mathrm{n} \\
\text { Squa } \\
\text { re }\end{array}$ & $\mathrm{F}$ & Sig. \\
\hline $1 \begin{array}{l}\text { Regressi } \\
\text { on }\end{array}$ & $\begin{array}{r}36,01 \\
9\end{array}$ & 2 & $\begin{array}{r}18,00 \\
9 \\
\end{array}$ & $\begin{array}{r}78,2 \\
06\end{array}$ & $\begin{array}{r}, 00 \\
0^{\mathrm{b}}\end{array}$ \\
\hline Residual & 9,672 & $\begin{array}{l}4 \\
2\end{array}$ & ,230 & & \\
\hline Total & $\begin{array}{r}45,69 \\
1\end{array}$ & $\begin{array}{l}4 \\
4\end{array}$ & & & \\
\hline \multicolumn{6}{|c|}{ a. Dependent Variable: SM } \\
\hline \multicolumn{6}{|c|}{ b. Predictors: (Constant), SA, SP } \\
\hline
\end{tabular}

Sumber: Hasil olah data SPSS 24

Berdasarkan tabel uji simultan diatas (Anova), diketahui nilai $F_{\text {hitung }}$ memiliki nilai sebesar 78,206 sedangkan $F_{\text {tabel }}$ nilai sebesar 3,21. Jadi nilai F Fitung lebih besar dari $F_{\text {tabel }}$ yaitu 78,206 > 3,21 dan nilai signifikan lebih kecil dari syarat signifikansi yaitu $0,000<0,05$, maka $\mathrm{H}_{3}$ diterima. Maka berdasarkan dari hasil pengujian dapat disimpulkan bahwa variabel stabilitas penjualan dan struktur aktiva berpengaruh signifikan terhadap struktur modal secara bersama-sama (simultan).

\section{Penutup}

\subsection{Kesimpulan}

1. Berdasarkan hasil pengujian hipotesis pertama dengan menggunakan uji $t$ (Parsial) yang telah diuraikan pada bab sebelumnya, maka hasil penelitian menyatakan bahwa $\mathrm{H}_{1}$ : diterima, stabilitas penjualan terdapat pengaruh signifikan terhadap struktur modal.

2. Berdasarkan hasil pengujian hipotesis pertama dengan menggunakan uji $t$ (Parsial) yang telah diuraikan pada bab sebelumnya, maka hasil penelitian menyatakan bahwa $\mathrm{H}_{2}$ : diterima, struktur aktiva terdapat pengaruh signifikan terhadap struktur aktiva. 
3. Berdasarkan hasil pengujian hipotesis pertama dengan menggunakan uji $f$ (Simultan) yang telah diuraikan pada bab sebelumnya, maka hasil penelitian menyatakan bahwa $\mathrm{H}_{3}$ : diterima, stabilitas penjualan dan struktur aktiva

4. berpengaruh signifikan terhadap struktur modal secara bersama-sama (simultan).

\subsection{Saran}

Berdasarkan kesimpulan diatas, penulis mengemukakan saran yang mungkin dapat bermanfaat:

Bagi Perusahaan

1. Diharapkan untuk lebih memperhatikan lagi faktor-faktor yang dapat mempengaruhi struktur modalnya. Serta perusahaan diharapkan meminimalisir penggunaan dana dari luar. Perusahaan sebaiknya meningkatkan kinerja penjualannya dengan demikian akan berpengaruh terhadap kemajuan dan nilai perusahaan dimasa akan datang.

2. Hasil ini memperlihatkan bahwa Stabilitas Penjualan dan Struktur Aktiva secara bersama-sama berpengaruh signifikan terhadap Struktur Modal. Hasil tersebut dapat dijadikan salah satu pertimbangan bagi manajemen perusahaan dalam menentukan kebijakan struktur modal untuk meningkatkan kinerja perusahaan sehingga mampu menjaga kepercayaan investor untuk berinvestasi di perusahaan.

Bagi Investor

1. Investor hendaknya memahami semua informasi yang relevan yang tersedia di pasar modal, baik melalui laporan keuangan yang dipublikasikan perusahaan atau informasi lain yang dirasa relevan. Investor juga sebaiknya mempertimbangkan berbagai macam faktor yang mempengaruhi struktur modal sebelum mengambil keputusan dalam berinvestasi di suatu perusahaan karena struktur modal mempengaruhi prospek suatu perusahaan ke depannya.

Bagi Peneliti Selanjutnya

1. Menambah jumlah sampel yang diteliti, tidak hanya meliputi perusahaan perdagangan (barang produksi dan barang konsumsi), tetapi dapat diperluas pada kelompok perusahaan lain yang terdaftar di Bursa Efek Indonesia.

2. Peneliti sebaiknya memperpanjang periode penelitian agar dapat diperoleh hasil penelitian yang lebih baik dan akurat.

3. Menambah variabel lain yang mempengaruhi struktur modal, baik yang berasal dari faktor internal maupun internal.

\section{DAFTAR PUSTAKA}

Ahmad, Rodoni dan Herni Ali., (2010). "Manajemen Keuangan". Jakarta: Mitra Wacana Media.

Arikunto, Suharsimi., (2010). "Prosedur Penelitian Suatau Pendekatan Praktik". Jakarta: Rineka Cipta.

Arikunto, Suharsimi., (2013). "Prosedur Penelitian Suatau Pendekatan Praktik". Jakarta: Rineka Cipta.

Atmaja, Lukas Setia., (2008). "Teori Dan Praktek Manajemen Keuangan”. Yogyakarta: Andi.

Brigham, Eugene dan Joel H. Houston., (2011). "Manajemen Keuangan II". Jakarta: Salemba Empat.

Brigham, Weston dan Houston., (2013). "Dasar-Dasar Manajemen Keuangan". Edisi Ke-11. Buku 2. Jakarta: Salemba Empat

Budi, Ratma Priatma dan Suryana., (2010). "Akuntansi Keuangan". Bandung: Ghalia Indonesia.

Bursa Efek Indonesia, http://www.idx.co.id ,[7 Oktober 2018].

Kioso, Donald E., (2008). "Akuntansi Intermediete". Terjemahan Emil Salim. 


\section{Erlangga.}

Jilid 1. Edisi Ke-10. Jakarta:

Lutfiyah., (2016). "Pengaru Penghematan

Pajak, Struktur Aktiva dan Tingkat Pertumbuhan terhadap Struktur

Modal". Jurnal Akuntansi

Ghozali, Imam., (2011). "Aplikasi Analisis

Multivariate Dengan Program SPSS". Semarang: Badan Penerbit

Universitas Diponogoro.

Ghozali, Imam., (2013). "Aplikasi Analisis

Multivariate Dengan Program SPSS". Edisi Ke-7. Semarang: Badan

Penerbit Universitas Diponogoro.

Harapah, Sofyan Syafri., (2013). "Analisis

Kritis Atas Laporan Keuangan". Jakarta: PT. Raja Grafindo Persada.

Ikatan Akuntanis Indonesia., (2009)

"Standar Akuntansi Keuangan". Jakarta: Salemba empat.

Ikatan Akuntansi Indonesia., (2012).

"Standar Akuntansi Keuangan". PSAK. Cetakan Ke-4. Jakarta: Salemba

\section{Empat.}

Irham, Fahmi., (2011). "Analisis Laporan

Keuangan". Bandung: Alfabeta.

Kasmir., (2013). "Analisis Laporan

Keuangan”. Jakarta: Rajawali Pers

Kasmir., (2013). "Analisis Laporan

Keuangan". Edisi 1. Cetakan Ke 6. Jakarta: Rajawali Pers.

Martono, dan Harijno, Agus., (2014).

"Manajemen Keuangan". Yogyakarta: Ekonisia.

Munawir., (2010). "Analisis Laporan

Keuangan”. Yogyakarta: Liberty.

Riyanto, Bambang., (2008). "Dasar-Dasar

Pembelanjaan Perusahaan". Yogyakarta:

Gajah Mada.

Riyanto, Bambang., (2010). "Dasar-Dasar Pembelanjaan Perusahaan”. Edisi 4. Yogyakarta: BPFE.

Romadhona, Aulia Ayu., (2017) "Pengaruh Penghematan Pajak, Struktur Aktiva dan
Pertumbuhan Perusahaan terhadap Struktur Modal". Jurnal Akuntansi.

Sahamok, http://www.sahamok.com , [4 Oktober 2018].

Santoso, Singgih., (2014). "Statistik Multivariat". Edisi Revisi. Jakarta: Elex Media Komputindo.

Sekaran, Uma., (2014). "Metodologi Penelitian Untuk Bisnis". Buku 1. Edisi Ke4. Jakarta: Salemba Empat.

Setyadi, Agus., (2017). "UMKM Sulit Dapat Modal Usaha". http://m.detik.com/finance/beritaekonomi-bisnis/d-3502490/umkmsulit-dapat-modal-usaha. Jakarta: Detik.com. [5 Januari 2018].

Sjahrial, Dermawan., (2009). "Manajemen Keuangan". Edisi 3. Jakarta: Mitra Wacana Media.

Sugiyono., (2010). "Metode Penelitian Kuantitatif Kualitatif Dan R\&D”. Bandung: Alfabeta.

Sugiyono., (2014). "Metode Penelitian Pendidikan Pendekatan Kuantitatif Kualitatif Dan R\&D”. Bandung: Alfabeta.

Sugiyono., (2015). "Metode Penelitian Kuantitatif Kualitatif Dan R\&D”. Bandung: Alfabeta.

Suharsapuutra, Uhar., (2014). "Metode Penelitian Kuantitatif Kualitatif Dan Tindakan". Bandung: Refika Aditama.

Syafri Harahap, Sofyan., (2008). "Analisa Kritis Atas Laporan Keuangan". Jakarta: PT. Raja Grafindo Persada.

Weston, J. Fred dan Copeland, Thomas. E., (2008). "Manajemen Keuangan". Jakarta: Binarupa Aksara.

Zulganef., (2008). "Metode Penelitian Sosial \& Bisnis". Yogyakarta: Graha Ilmu.

\section{ONLINE}

Abidah, Mahjati., (2013). "Pengaruh Pertumbuhan Perusahaan, Stabilitas Penjualan, Profitabilitas dan Ukuran 
Perusahaan terhadap Struktur Modal (Studi Empiris Pada Perusahaan Consumer Goods yang Terdaftar di BEI periode 20092011)". Dalam e-journal S1 Ak Universitas Negeri Yogyakarta.

Febriany, Eka Putri., (2017). "Pengaruh Profitabilitas, Leverage Operasi, Stabilitas Penjualan, Struktur Aktiva, Tingkat Pertumbuhan dan Ukuran Perusahaan terhadap Struktur Modal Perusahaan Manufaktur yang Terdaftar di BEI". Universitas Hasanudin.[Online].

Maryanti, Eny., (2016). "Analisis Profitabilitas, Pertumbuhan Perusahaan, Pertumbuhan Penjualan dan Struktur Aktiva terhadap Struktur Modal (Studi Empiris Pada Perusahaan Manufaktur yang Terdaftar di BEI periode 2012-2014)". Riset Akuntansi dan Keuangan Indonesia, 1(2), 2016.

Manopo, Widy Fimber., (2013). "FaktorFaktor yang Mempengaruhi Struktur Modal Perbankan yang Go Public di BEI periode 2008-2010)". Jurnal EMBA.[Online].

Vol.1 No.3.

Mawikere, Cinthia Yurike., dan Rate, Paulina Van., (2015). "Pengaruh Stabilitas Penjualan dan Struktur Aktiva terhadap Struktur Modal Perusahaan Automotive and Allied Product yang Terdaftar di BEI Periode 2010-2013". Jurnal EMBA.[Online]. Vol.3 No.3.

Priambodo, Taruna Johni., Topowijono., Azizah Devi Farah., (2014). "Pengaruh Struktur Aktiva, Tingkat

Pertumbuhan Penjualan dan Profitabilitas terhadap Struktur Modal (Studi

Empiris pada Perusahaan Tekstil dan Garmen yang listing di BEI periode 2010-2012)". Jurnal Administrasi Bisnis (JAB).[Online]. Vol.9 No.1. http://www.administrasibisnis.stude ntjournal.ub.ac.id

Putri, Meidera Elsa Dwi., (2012). "Pengaruh Profitabilitas, Struktur Aktiva dan Ukuran Perusahaan tehadap Struktur Modal (Studi Empiris pada Perusahaan Manufaktur Sektor Industri Makanan dan Minuman yang Terdaftar di BEI)". Jurnal Manajemen.[Online]. Vol.1 No.1.

Thausyah, Nudzunul Fiara., (2015). "Pengaruh Pertumbuhan Penjualan, Struktur Aktiva dan Profitabilitas terhadap Struktur Modal." Jurnal Ilmu dan Riset Manajem 